Article

\title{
Using Thermal Shock to Inhibit Biofilm Formation in the Treated Sewage Source Heat Pump Systems
}

\author{
Siyuan Chang ${ }^{1}$, Jinchun Chen ${ }^{2}$ and Lin Shi ${ }^{1, *}$ \\ 1 Key Laboratory for Thermal Science and Power Engineering of Ministry of Education, \\ Department of Thermal Engineering, Tsinghua University, Beijing 100084, China; changsiyuan1226@163.com \\ 2 Laboratory of Microbiology, School of Life Sciences, Tsinghua University, Beijing 100084, China; \\ chenjc@mail.tsinghua.edu.cn \\ * Correspondence: rnxsl@mail.tsinghua.edu.cn; Tel.: +86-10-62787613
}

Academic Editor: Takahiko Miyazaki

Received: 30 December 2016; Accepted: 24 March 2017; Published: 30 March 2017

\begin{abstract}
Treated sewage source heat pump systems can reuse the waste energy in the treated sewage. However, biofilms in the heat exchangers decrease the system efficiency. This work investigates the feasibility of thermal shock at accessible temperatures in heat exchangers for biofilm inhibition. Bacillus subtilis biofilms were formed on coupons and in a miniaturized plate heat exchanger. Thermal shocks at different temperatures $\left(50-80{ }^{\circ} \mathrm{C}\right)$ for different exposure times $(1-60 \mathrm{~min})$ were used to treat the biofilms. The results showed that thermal shock had a significant bactericidal and biofilm inhibition effect, and the effect was enhanced as the temperature and the exposure time increased. Data fitting of the biomass showed that temperature had a more significant influence on the biofilm inhibition effect than exposure time. The results of the heat exchanging experiments showed that high temperature thermal shock could significantly mitigate the heat transfer deterioration caused by the biofilms, indicating that thermal shock could be used as a viable biofilm inhibition approach for heat exchangers.
\end{abstract}

Keywords: treated sewage source heat pump systems; thermal shock; biofilm inhibition; temperature; exposure time

\section{Introduction}

Treated sewage, which contains a large amount of urban low-rank energy, is an ideal heat and cooling source [1,2]. Its temperature $\left(20-30^{\circ} \mathrm{C}\right)$ is ideal for maintaining a high efficiency for heat pump operations [3-5]. Treated sewage source heat pump systems (TSSHPS) can reuse the waste energy contained in the treated sewage for building heating and cooling [6], and many practical projects, such as the 2008 Beijing Olympic Village TSSHPS, have come into service and been proved to be efficient $[7,8]$.

However, the high bacterial concentration and the rich nutrient environment in the treated sewage cause biofilm formation on the stainless steel plates in the plate heat exchangers [9-11], which are important components in the TSSHPS to transfer heat from the treated sewage to the clean working medium due to their compactness and high thermal efficiency [12]. Biofilms reduce the heat transfer coefficient of the heat exchangers and the coefficient of performance of the whole heat pump system. A previous study has reported that biofilms were formed within 40 days of operation in a TSSHPS and the coefficient of performance of the system decreased by $50 \%$ [13].

Biofilms, defined as a complex community of microbes settled to a solid substrate and encased in the extracellular polymeric substance [14,15], or the EPS, is a refractory problem for heat-exchanging systems, food processing equipment, medical instruments, and hull surfaces, etc. [16-19]. Regarding the formation process of the biofilms, first, microorganisms, such as bacteria, attach to the biotic or 
abiotic surfaces. Then the microorganisms form microbial colonies and secret EPS, which is mainly composed of polysaccharides, proteins, nucleic acids, etc., and acts as a "glue". Finally, the biofilm develops into a matured porous structure, which protects the microorganisms from hazard external environments, such as high concentration of bactericides and oligotrophic conditions, and help them gain ecological advantages [20-22].

Due to the serious losses caused by biofilms, innovative biofilm inhibition and elimination strategies are constantly being sought [23,24]. Physical approaches, such as coatings, micro-patterned surfaces and gas discharge plasmas, have been reported to inhibit bacteria settlement and disturb biofilm structures [25-27]. Antimicrobial agents have been tested against biofilms and were found effective in killing the indwelling organisms [28,29]. Various peptides and enzymes have been used to inhibit biofilm formation [30].

However, many of these strategies are limited when applied to the TSSHPS. Micro-patterned surfaces and biofilm-inhibition coatings are limited as they are costly and might lead to extra thermal resistance in the heat exchangers. Due to the enclosed environment of the plate heat exchangers, external biofilm-inhibition forces, such as gas discharge plasmas, would be difficult to be used. Additonally, as the treated sewage is in large flow rate and drained to nearby rivers after the heat transfer process, the application of chemical and biological antimicrobial agents is limited due to the large consumption and environmental protection concerns [11].

Among the many strategies, thermal shock at accessible temperatures $\left(\leq 80^{\circ} \mathrm{C}\right)$ might prove to be a more feasible and effective approach towards biofilm inhibition in plate heat exchangers. Thermal shock could be applied to the biofilms just by adding another pathway to the plate heat exchanger and inletting hot water at regular intervals during TSSHPS operation. Compared with the majority existing biofilm-inhibition approaches, thermal shock is easy to realize and would not lead to high costs or harms to the environment.

Thermal shock is commonly used for bacteria inactivation. Pasteurization for milk and liquid foods sterilization has been used for over a century [31] and autoclaving $\left(>120^{\circ} \mathrm{C}\right)$ has been used for biofilm sterilization on medical equipment surfaces [32]. Many studies have investigated thermal inactivation of bacteria, and various models of the bacterial survival curves have been developed [33-36].

Among these studies, many focused on the inactivation of planktonic bacteria. However, it has been reported that biofilms protected the indwelling microorganisms and it was much harder to inactivate the bacteria in biofilms and inhibit the biofilm formation [37]. The inhibition effect of thermal shock on biofilms might differ from that on planktonic bacteria. Several studies have considered using thermal shock for biofilm inhibition [38-40], but few have investigated using thermal shock to inhibit biofilms in heat exchangers in the TSSHPS and the inhibition mechanism has not been fully studied. Furthermore, most of the existing studies focused on parameters, such as biofilm weight and the number of live bacteria in the biofilms, not many studies have investigated the thermal resistance caused by the biofilms in the heat exchangers.

This study have investigated the biofilm inhibition effect and mechanism of thermal shock. Model sewage was used to form biofilms, both in a rotating coupon device and in a plate heat exchanger, and the biofilms were thermal shocked at regular intervals. Balance weighing, confocal laser scanning microscope (CLSM) picturing and thermal resistance monitoring have been used to analyze the biofilms. The results showed that thermal shock significantly inactivated the bacteria in the biofilms and, thus, inhibited biofilm growth, and the inhibition effect was enhanced as the temperature and exposure time increased. Additionally, thermal shock significantly mitigated the biofilm thermal resistance and could be used as a potential inhibition approach for biofilms in the plate heat exchangers.

This study has investigated the biofilm inhibition effect and mechanism of thermal shock. Model sewage was used to form biofilms, both in a rotating coupon device and in a plate heat exchanger, and the biofilms were thermal shocked at regular intervals. Balance weighing, CLSM picturing, and thermal resistance monitoring have been used to analyze the biofilms. The results showed that thermal 
shock significantly inactivated the bacteria in the biofilms and, thus, inhibited biofilm growth and the inhibition effect was enhanced as the temperature and exposure time increased. Furthermore, thermal shock significantly decreased the biofilm thermal resistance and could be used as a potential inhibition approach for biofilms in the heat exchangers.

\section{Materials and Methods}

\subsection{Organism and Inoculum}

A previous study [41] has shown that the dominant bacteria of the treated sewage in six Beijing sewage plants was Bacillus sp. $(>62 \%)$. B. subtilis CCL716 was used in this study and was kindly provided by the Biomedical Engineering Department in Tsinghua University. The bacterium solution was mixed with $100 \%$ glycerol at a $1: 1$ ratio and stored at $-80^{\circ} \mathrm{C}$. For each trial, the samples were plate streaked on LB agars (Thermo Fisher, Shanghai, China) and incubated at $30^{\circ} \mathrm{C}$ for $24 \mathrm{~h}$ to form single colonies. A single colony was picked and inoculated to the culture solution, which consisted of $0.5 \mathrm{wt} \%$ beef extract, $1 \mathrm{wt} \%$ peptone, $1 \mathrm{wt} \%$ glucose, and $0.5 \mathrm{wt} \% \mathrm{NaCl}$ (Sinopharm, Beijing, China). Prior to inoculation, the culture solution was autoclaved at $121^{\circ} \mathrm{C}$ for $30 \mathrm{~min}$. The culture solution inoculated with B. subtilis was then incubated in a shaker at $30^{\circ} \mathrm{C}$ at $200 \mathrm{rpm}$ for $24 \mathrm{~h}$ to reach a final bacterial concentration of approximately $1.0 \times 10^{9} \mathrm{CFU} / \mathrm{mL}$.

\subsection{Model Sewage Preparation}

Water quality, including bacteria concentration, biological oxygen demand (BOD), inorganic ion concentration, temperature and $\mathrm{pH}$, of the treated sewage in Beijing has been monitored in a previous study [8]. The model sewage for biofilm formation in this study was prepared according to these parameters. Briefly, the cultured bacterium solution was diluted to ultra-filtered water to reach a bacteria concentration of $1.0 \times 10^{5} \mathrm{CFU} / \mathrm{mL}$, which was the average value of bacteria concentration of the treated sewage during summer operating conditions in the TSSHPS. Additionally, solutions of sodium hydroxide, glucose, and calcium chloride were added to this bacterium solution to adjust the $\mathrm{pH}, \mathrm{BOD}$, and the $\mathrm{Ca}^{2+}$ concentration to $7.2,15$, and $65 \mathrm{mg} / \mathrm{L}$, which were the average values of the treated sewage during summer operating conditions. In such a way, the model sewage with certain parameters was prepared and then used for biofilm formation experiments.

\subsection{The Rotating Coupon Device and Biofilm Formation Procedure}

A rotating coupon device (RCC-3, Motian Tech., Suzhou, China) was used in this study for biofilm formation. The schematic diagram of the setup is shown in Figure 1.

(A)

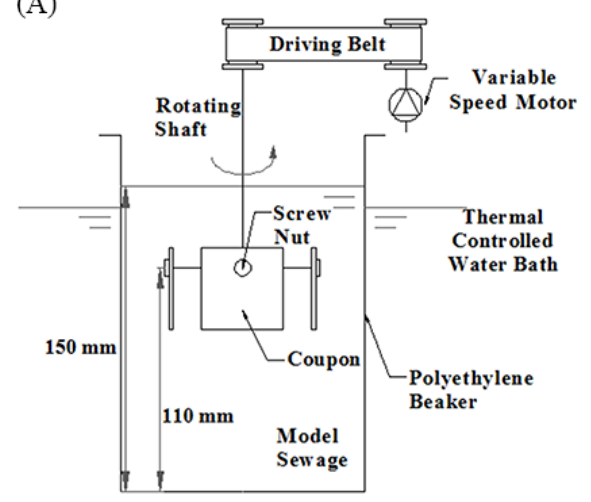

(B)

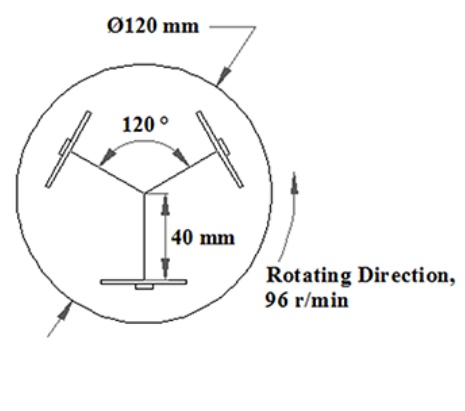

Figure 1. Schematic diagram of the rotating coupon device: (A) front view; and (B) top view.

The prepared model sewage was contained in a polyethylene beaker, and the beaker was placed in the thermally-controlled water bath of the rotating coupon device. The temperature of the water 
bath was set at $25^{\circ} \mathrm{C}$, which was the average treated sewage temperature during summer operating conditions. A T thermocouple (GG-T-20, Omega, Shanghai, China) was put at the geometric center of the beaker and was connected to a data logger (34970A, Agilent, Shanghai, China) to monitor the temperature in the beaker. The results showed that the temperature in the beaker reached $25^{\circ} \mathrm{C}$ within $30 \mathrm{~min}$ and remained at $25 \pm 0.5^{\circ} \mathrm{C}$ during the whole process.

Three stainless steel coupons (AISI 316, $20 \mathrm{~mm} \times 20 \mathrm{~mm} \times 1 \mathrm{~mm}$ ) were fixed onto the rotating shaft using screw nuts. Then the coupons were immersed and rotated in the model sewage. The angular velocity was set at $96 \mathrm{rpm}$, and the linear velocity at the coupon surfaces was $0.4 \mathrm{~m} / \mathrm{s}$, which was a common flow velocity in plate heat exchangers in the TSSHPS.

This biofilm formation process lasted for $120 \mathrm{~h}$, and every $12 \mathrm{~h}$ fresh model sewage was prepared to replace the old model sewage in the beaker. A previous study [6] has reported that $120 \mathrm{~h}$ were sufficient for the biomass to reach a stable phase.

\subsection{Thermal Shock}

Every $24 \mathrm{~h}$ during the biofilm formation process, the biofilms on the coupons were thermal shocked at a designed temperature $\left(50,60,70\right.$, and $\left.80^{\circ} \mathrm{C}\right)$ for a designed exposure time $(1,2,5,10,30$, and $60 \mathrm{~min})$.

Briefly, water-filled vials were pre-heated in a water bath (WB1110C-1, Thermo Fisher, Shanghai, China) to the designed temperature. A T thermocouple (GG-T-20, Omega, Shanghai, China) was put in the geometric center of each vial to monitor the temperature in the vial. The results showed that during the thermal shock processes, the temperature in the vials remained at the designed temperature $\pm 0.2^{\circ} \mathrm{C}$.

After the water in the vials reached the designed temperature, the coupons were quickly taken off from the rotating coupon device and placed in the vials to be thermal shocked for a designed exposure time. For the control group, the coupons were taken off from the rotating coupon device and placed in $25{ }^{\circ} \mathrm{C}$ water for the designed exposure time. Then the coupons were re-fixed to the rotating coupon device to continue the biofilm formation process.

\subsection{Biomass}

Every $24 \mathrm{~h}$ during the biofilm formation process, the coupons were weighed to determine the biomass of the biofilms.

Prior to being weighed, the coupons were taken off from the shaft and suspended vertically in air for $5 \mathrm{~min}$ to drain off the surface water-droplets. Then the coupons were weighed using a balance (XS105, Mettler Toledo, Zurich, Switzerland) with a precision of $\pm 0.1 \mathrm{mg}$.

The biomass per unit area was determined as:

$$
m_{\mathrm{f}}=\frac{M_{\mathrm{f}}-M_{\mathrm{c}}}{S}
$$

where $M_{\mathrm{f}}$ is the weight of the coupon with the biofilm (g), $M_{\mathrm{c}}$ is the weight of the clean coupon $(\mathrm{g}), S$ is the surface area of the coupon $\left(\mathrm{m}^{2}\right)$ and $m_{\mathrm{f}}$ is the biomass per unit area $\left(\mathrm{g} / \mathrm{m}^{2}\right)$. For each trial, three coupons, which were in the same beaker and treated with the same temperature and exposure time, were used as replicates $(n=3)$.

\subsection{CLSM Picturing}

The $24 \mathrm{~h}, 72 \mathrm{~h}$, and $120 \mathrm{~h}$ biofilms were observed using a CLSM to investigate the cell viability and the biofilm thickness.

Prior to being pictured by the CLSM, the biofilms were stained with two fluorescent nucleic acid dyes, propidium iodide (PI), and SYTO ${ }^{\circledR} 9\left(\right.$ BacLight $^{\circledR}$ bacterial viability kit, Invitrogen, Shanghai, China). Briefly, $3 \mu \mathrm{L}$ PI and $3 \mu \mathrm{L}$ SYTO ${ }^{\circledR} 9$ were added to $1000 \mu \mathrm{L}$ deionized water. Then the coupons were quickly taken from the rotating coupon device and each covered with $500 \mu \mathrm{L}$ of the staining 
solution and stained for $25 \mathrm{~min}$ in dark, followed by $5 \mathrm{~min}$ rinsing to remove the stain residuals. The stained coupons were then viewed using a CLSM (LSM 710, Carl Zeiss, Oberkochen, Germany) with a $40 \times$ objective lens. Five random fields of view were imaged for each sample. Each field covered a surface area of $212.3 \times 212.3 \mu \mathrm{m}$ and Z-stack images were obtained using the software ZEN 2010 (version 2.3, Carl Zeiss, Oberkochen, Germany, 2010). The image stacks were imported to the software IMARIS (version 7.2.3, Bitplane, Zurich, Switzerland, 2012), and the "Smart 3D" and "Surface" functions of the software were used for 3D reconstruction and biovolume calculation of the biofilms, according to the tutorials provided by the software developer [42].

\subsection{Pilot Heat Exchanging System}

A pilot heat exchanging system was used to investigate the biofilm inhibition effect of thermal shock on biofilms in a miniaturized plate heat exchanger. The schematic diagram of the system is shown in Figure 2.

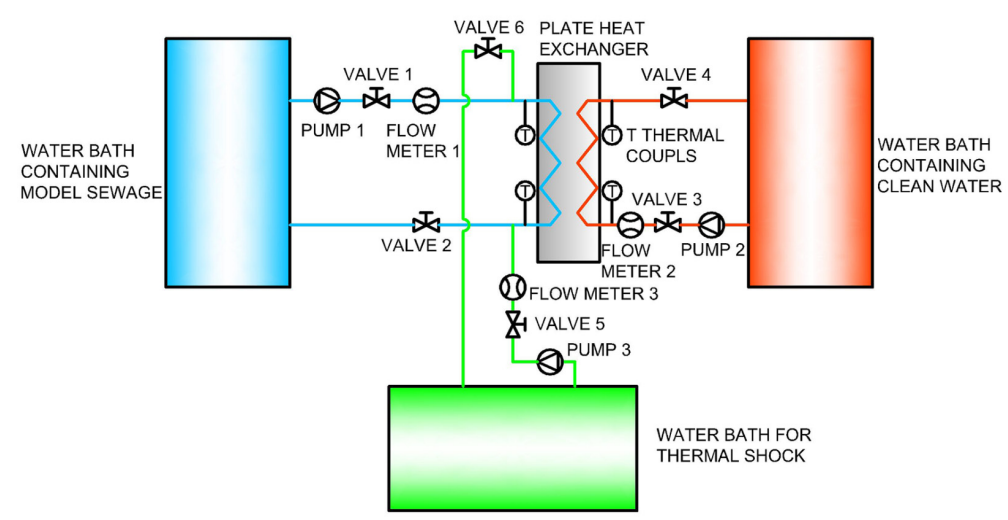

Figure 2. Schematic arrangement of the pilot heat exchanging system in the TSSHPS.

For the biofilm formation stage, Valves 1, 2, 3, and 4 were open and valves 5 and 6 were closed. Model sewage and clean water were contained in the two water baths (HX-1050, Biocool Tech., Beijing, China) and pumped into the plate heat exchanger (CB10, Alfa Laval, Shanghai, China) to exchange heat. The temperatures of the model sewage and the clean water were set at 25 and $30{ }^{\circ} \mathrm{C}$, which was a typical summer operating condition in the TSSHPS. Biofilms were formed in the heat exchanger as the model sewage flew through and the heat transfer coefficient would decrease. The flow rates, inlet and outlet temperatures of the model sewage and clean water were monitored by the flow meters and the $\mathrm{T}$ thermocouples, and stored on a computer to calculate the heat transfer coefficient of the plate heat exchanger and the thermal resistance of the biofilms. This biofilm formation process lasted for $120 \mathrm{~h}$ and every $12 \mathrm{~h}$ fresh model sewage was prepared to replace the old model sewage in the water bath.

Every $24 \mathrm{~h}$, the biofilms were thermal shocked. For the thermal shock stage, the clean water in the third water bath (HX-1050, Biocool Tech., Beijing, China) was preheated to the designed temperature. Then valves 1 and 2 were closed and valves 5 and 6 were opened. Biofilms in the heat exchanger were treated with hot water for the designed exposure time. Then valves 5 and 6 were closed and valves 1 and 2 were opened to continue the biofilm formation process. Different thermal shock protocols with different temperature and exposure times $\left(50{ }^{\circ} \mathrm{C}-30 \mathrm{~min} / 24 \mathrm{~h}, 65^{\circ} \mathrm{C}-10 \mathrm{~min} / 24 \mathrm{~h}, 80^{\circ} \mathrm{C}-5 \mathrm{~min} / 24 \mathrm{~h}\right.$ and $25^{\circ} \mathrm{C}-30 \mathrm{~min} / 24 \mathrm{~h}$ as the control group) were investigated.

The thermal resistance of the biofilms, $R_{\mathrm{f}}\left(\mathrm{m}^{2} \cdot \mathrm{K} / \mathrm{W}\right)$, was calculated by:

$$
R_{\mathrm{f}}=\frac{1}{h_{\mathrm{f}}}-\frac{1}{h_{0}}
$$

where $h_{\mathrm{f}}\left(\mathrm{W} / \mathrm{m}^{2} \cdot \mathrm{K}\right)$ was the heat transfer coefficient of the heat exchanger with biofilms and $h_{0}$ $\left(\mathrm{W} / \mathrm{m}^{2} \cdot \mathrm{K}\right)$ was the heat transfer coefficient of the clean heat exchanger. 
The heat transfer coefficient, $h\left(\mathrm{~W} /\left(\mathrm{m}^{2} \cdot \mathrm{K}\right)\right)$, was calculated by:

$$
h=\frac{\rho c_{\mathrm{p}}\left[Q_{\mathrm{V}, \mathrm{m}}\left(T_{\mathrm{m}, \text { out }}-T_{\mathrm{m}, \text { in }}\right)+Q_{\mathrm{V}, \mathrm{c}}\left(T_{\mathrm{c}, \text { in }}-T_{\mathrm{c}, \text { out }}\right)\right]}{A\left(T_{\mathrm{c}, \text { in }}-T_{\mathrm{m}, \text { out }}+T_{\mathrm{c}, \text { out }}-T_{\mathrm{m}, \text { in }}\right)}
$$

where $T_{\mathrm{m} \text {,out }}, T_{\mathrm{m} \text {,in }}, T_{\mathrm{c}, \text { out }}, T_{\mathrm{c}, \text { in }}$ were the outlet and inlet temperatures of the model sewage and the clean water $\left({ }^{\circ} \mathrm{C}\right), Q_{\mathrm{v}, \mathrm{m}}$, and $Q_{\mathrm{v}, \mathrm{c}}$ were the flow rate of the model sewage and the clean water $\left(\mathrm{m}^{3} / \mathrm{s}\right), \rho$ was the water density $\left(996 \mathrm{~kg} / \mathrm{m}^{3}\right), c_{\mathrm{p}}$ was specific heat at constant pressure of water $\left(4.18 \times 10^{3} \mathrm{~J} /(\mathrm{kg} \cdot \mathrm{K})\right)$ and $A$ was the equivalent heat transfer area of the heat exchanger $\left(\mathrm{m}^{2}\right)[41,43]$.

\subsection{Statistical Analysis}

In this study, the results were reported in a way of mean value \pm standard deviation (SD). The statistics were analyzed with analysis of variance (ANOVA), and the analyses (ANOVA and data fitting) were performed using MATLAB (version 8.3, Mathworks, Beijing, China, 2014).

\section{Results}

\subsection{Biomass}

The biomass development of the thermal shocked biofilms during the $120 \mathrm{~h}$ process is shown in Figure 3.
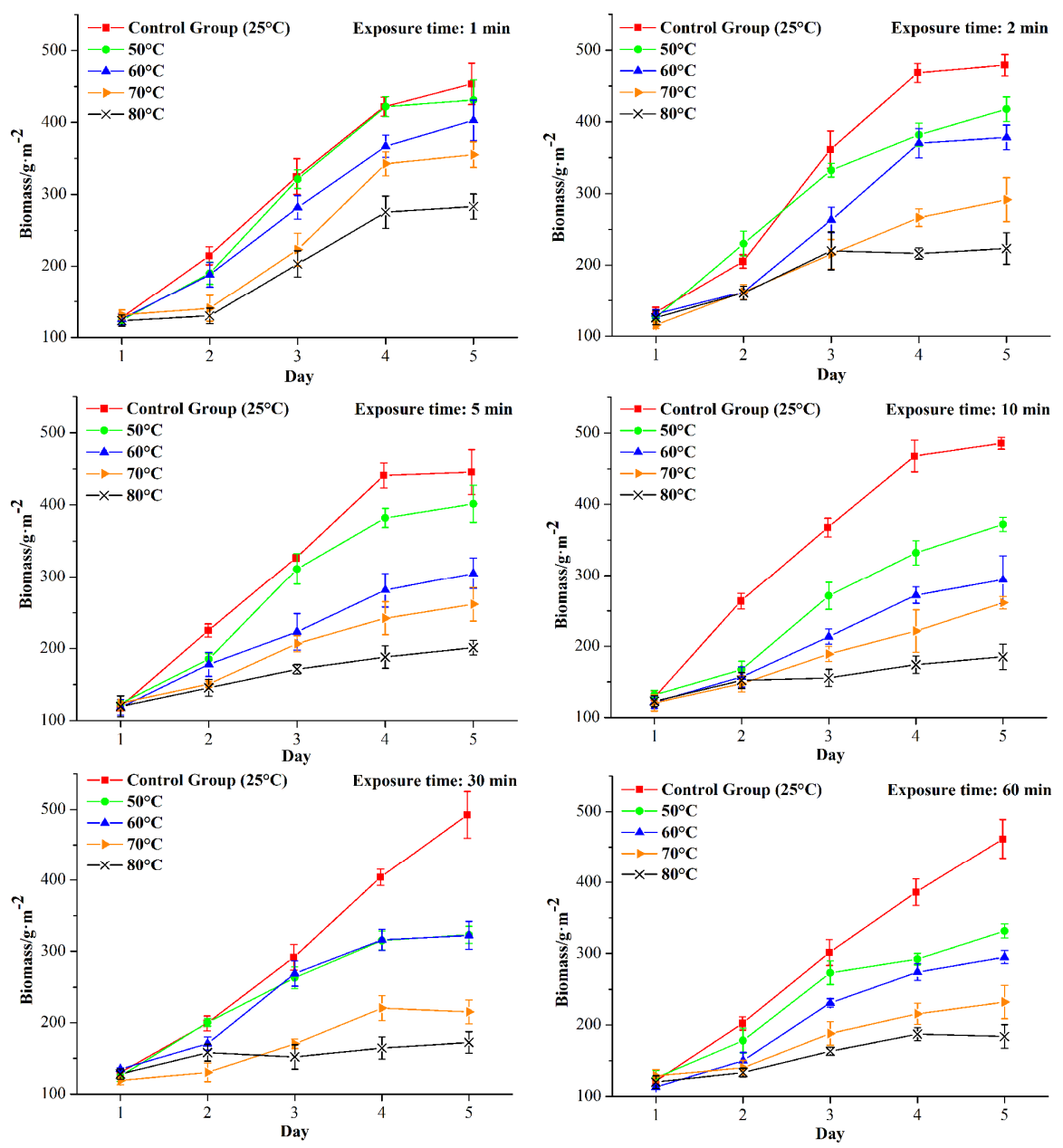

Figure 3. Biomass development of the thermally-shocked biofilms. 
It can be seen in Figure 3 that, during the $120 \mathrm{~h}$ process, biofilms formed on the coupons and the biomass increased over time as the coupons were rotated in the model sewage. The biomass of the control group $\left(25^{\circ} \mathrm{C}\right)$ increased to $400-500 \mathrm{~g} / \mathrm{m}^{2}$, which was consistent with the results in a previous study [6]. Additionally, it can be seen that, for a certain exposure times, the biomass decreased and the biofilm inhibition effect was enhanced as the temperature increased.

To get a further understanding of the influence of temperature and exposure time, the $120 \mathrm{~h}$ biomass of the biofilms treated with different temperatures and exposure times is shown in Figure 4 .

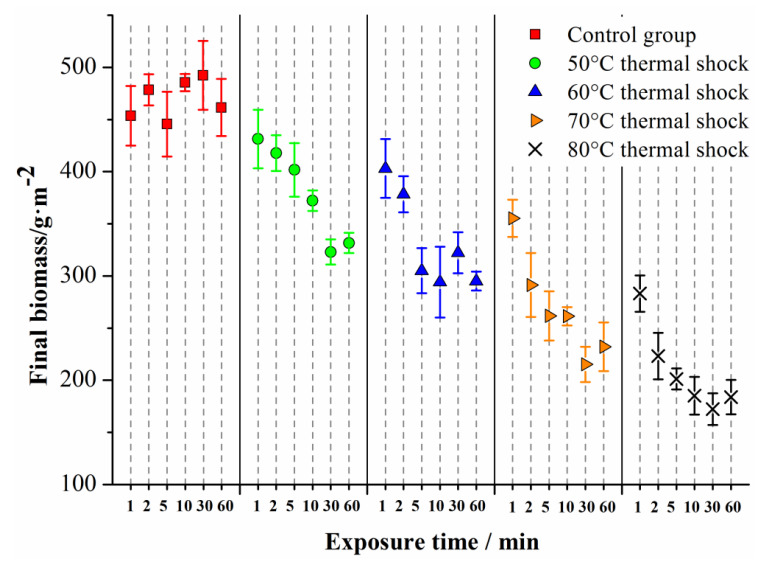

Figure 4. Biomass $(120 \mathrm{~h})$ of biofilms thermally-shocked with different temperatures and exposure times.

As can be seen in Figure 4, the biomass of the control group did not change significantly as the exposure time increased $(p=0.540, n=3)$, and the average value of the biomass in the control group was $469 \mathrm{~g} / \mathrm{m}^{2}$. For the thermal shocked biofilms, however, at a certain temperature, the biomass decreased as the exposure time increased. Meanwhile, when comparing the main columns in Figure 4, it can be seen that the overall biomass decreased as the temperature increased. Two-way ANOVA showed that the biomass decreased significantly as the temperature and exposure time increased ( $p<0.01$ for temperature and $p<0.01$ for exposure time, $n=3$ ), indicating a significantly enhanced the biofilm inhibition effect of the thermal shock as the temperature and exposure time increased.

\subsection{Data Fitting of the $120 \mathrm{~h}$ Biomass}

Data fitting of the $120 \mathrm{~h}$ biomass as a function of the exposure time was performed using the "cftool" function in the software MATLAB. As the biomass of the control group $\left(25^{\circ} \mathrm{C}\right)$ did not change significantly with the exposure time, the average value of the six biomass in the control group, $469 \mathrm{~g} / \mathrm{m}^{2}$, was used as the biomass without being thermal shocked for data fitting. The fitting formula is shown in Equation (4):

$$
m_{\mathrm{f}}=m_{\mathrm{f}, \text { ave } \_25^{\circ} \mathrm{C}}-a \times\left(1-\mathrm{e}^{-b t}\right)
$$

where $m_{\mathrm{f}}$ is the biomass of the thermal shocked biofilms $\left(\mathrm{g} / \mathrm{m}^{2}\right), m_{\mathrm{f}, \text { ave } \_25}{ }^{\circ} \mathrm{C}$ is the average biomass of the control group $\left(469 \mathrm{~g} / \mathrm{m}^{2}\right), a$ and $b$ are coefficients correlated with temperature $\left(\mathrm{g} / \mathrm{m}^{2}\right.$ and $\left.\mathrm{min}^{-1}\right)$ and $t$ is the exposure time ( $\mathrm{min}$ ). The reason for choosing Equation (4) as the fitting formula will be discussed and the fitting results are shown in Figure 5.

It can be seen in Figure 5 that the biomass decreased in a negative-exponential form as the exposure time increased and Equation (4) yielded tight correlations with average $R^{2}$ in different temperature groups larger than 0.92 .

The coefficients $a$ and $b$ increased as the temperature rose from 50 to $80^{\circ} \mathrm{C}$. Coefficients $a$ and $b$ were fitted as functions of the temperature rise (compared with $25^{\circ} \mathrm{C}$ ) in a linear form and the results are shown in Figure 6. 

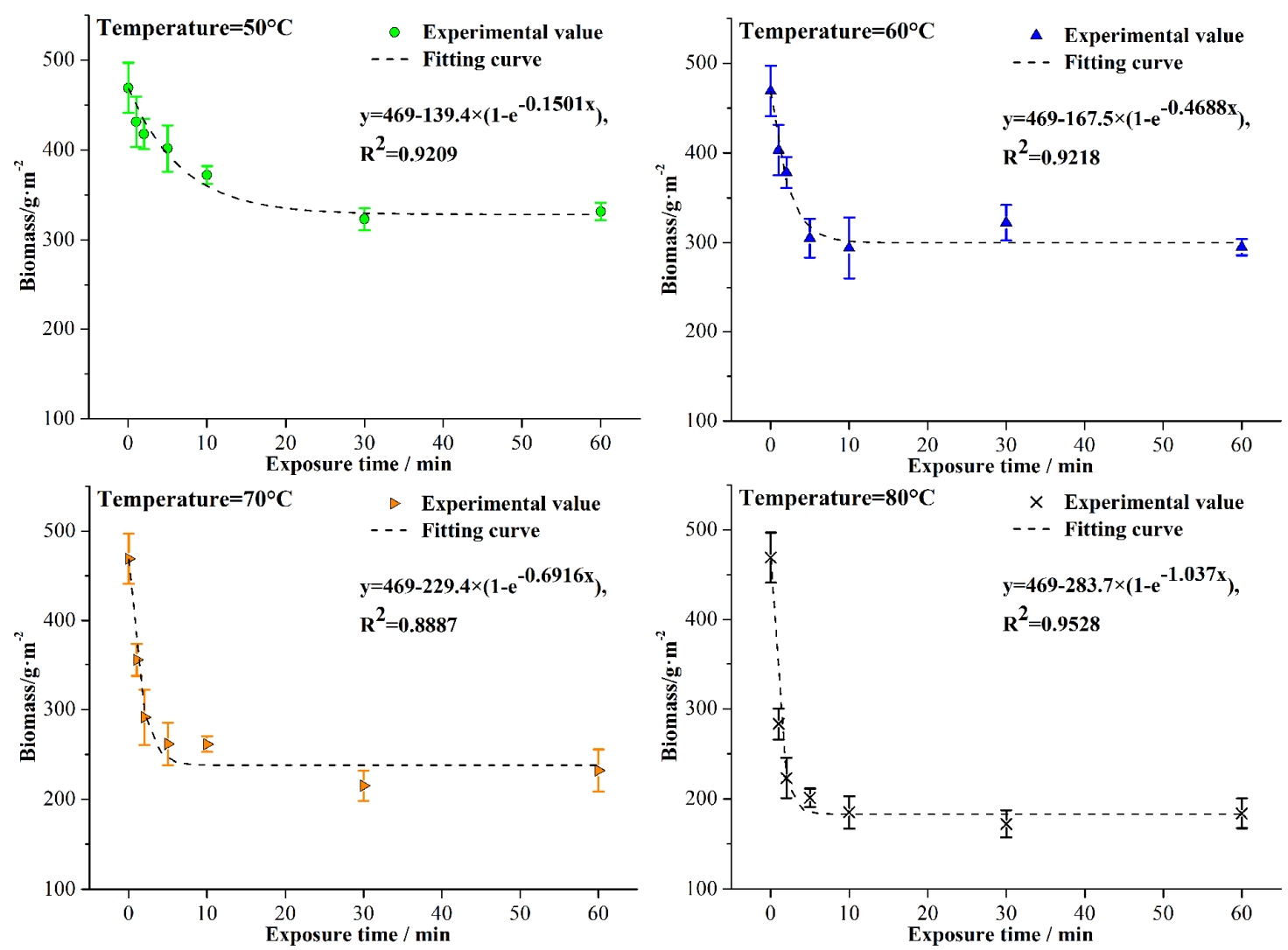

Figure 5. Data fitting of the $120 \mathrm{~h}$ biomass as a function of exposure time.
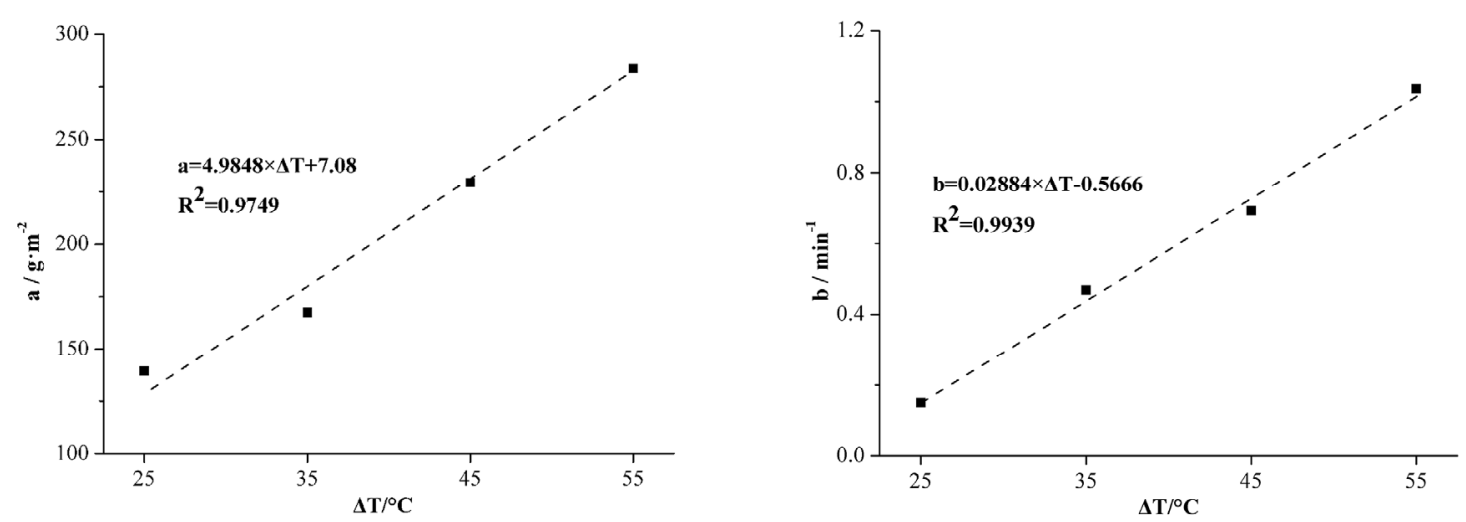

Figure 6. Data fitting of the coefficients $a$ and $b$ as functions of the temperature rise.

Given the expression of $a$ and $b$ in Figure 6, the fitting equation of the $120 \mathrm{~h}$ biomass as a function of the temperature and the exposure time can be written as:

$$
m_{\mathrm{f}}=469-[4.9848 \times(T-25)+7.08] \times\left\{1-\mathrm{e}^{-[0.02884 \times(T-25)-0.5666] \times t}\right\}
$$

where $T$ is the temperature $\left({ }^{\circ} \mathrm{C}\right)$ and $t$ is the exposure time (min).

\subsection{CLSM Imaging of the Biofilms and Quantitative Analysis}

In this study, the biofilms were stained with fluorescent dyes and viewed with a CLSM, and the CLSM images of the $120 \mathrm{~h}$ biofilms are shown in Figure 7. 


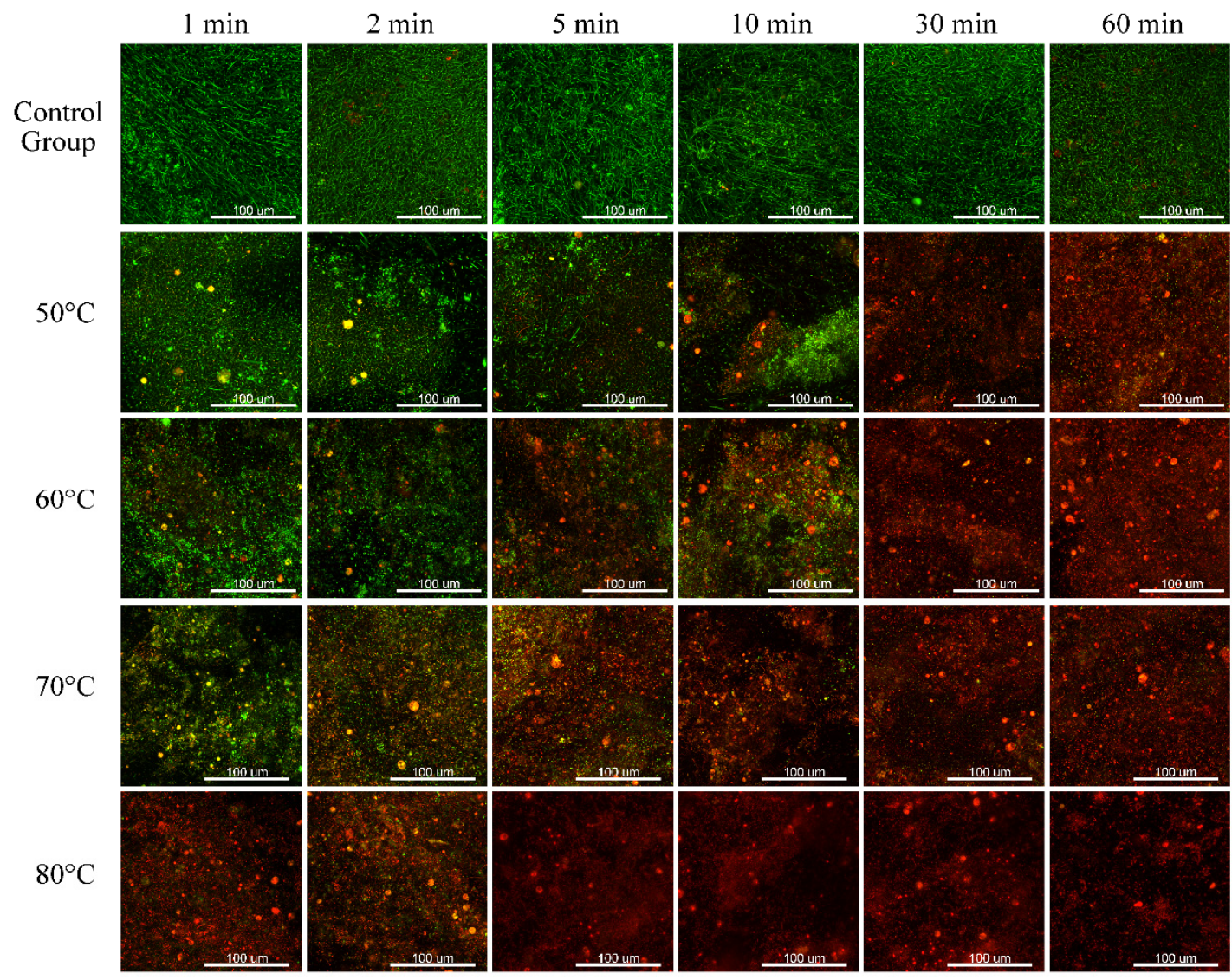

Figure 7. CLSM images of the $120 \mathrm{~h}$ biofilms thermally-shocked with different temperatures and exposure times.

As can be seen in Figure 7, for the biofilms in the control group, the majority of the cells were alive (green fluorescence), regardless of the exposure time, suggesting that immersing with normal temperature water has no bactericidal effect.

For the biofilms treated with $50{ }^{\circ} \mathrm{C}$ water, when the exposure time was short (less than $10 \mathrm{~min}$ ), only a few bacteria in the outer layer were inactivated (red fluorescence). As the exposure time increased, more cells were killed. When the exposure time was long (more than $30 \mathrm{~min}$ ), the majority of the cells were dead and only few interior cells, which were protected by the biofilm layer, were alive.

A similar trend, that more cells were killed as the exposure time increased, was shown in the CLSM pictures of biofilms treated at 60,70 , and $80^{\circ} \mathrm{C}$. However, as the temperature increased, the exposure time required to inactivate the majority of the cells decreased. Specifically, for the biofilms thermal shocked at $80^{\circ} \mathrm{C}$, even for a very short exposure time (1 and $2 \mathrm{~min}$ ), the majority of the cells were inactivated and only a few bacteria in the bottom layers remained alive. When the exposure time increased, nearly all of the cells were killed, suggesting a significant bactericidal effect of the thermal shock at such a temperature.

Additionally, when comparing biofilms thermally-shocked for the same exposure time, but at different temperatures, it can be seen that as the temperature increased, more cells were killed, suggesting an enhanced bactericidal effect as the temperature increased.

Regarding the structure of the biofilms, matured, porous, and dense structures of the biofilms were observed in the control group, suggesting that immersing at a normal temperature has no inhibiting effect on the biofilm formation. As the temperature and the exposure time increased, it could be seen that the biofilms became thinner and more black area could be observed, suggesting that the thermal shock decreased the volume and surface coverage rate of the biofilms. 
Furthermore, Imaris was used to calculate the biovolume of the live cells and dead cells according to the amount of green and red fluorescence, and the ratio of the live cell biovolume to the dead cell biovolume at $120 \mathrm{~h}$ is shown in Figure 8.

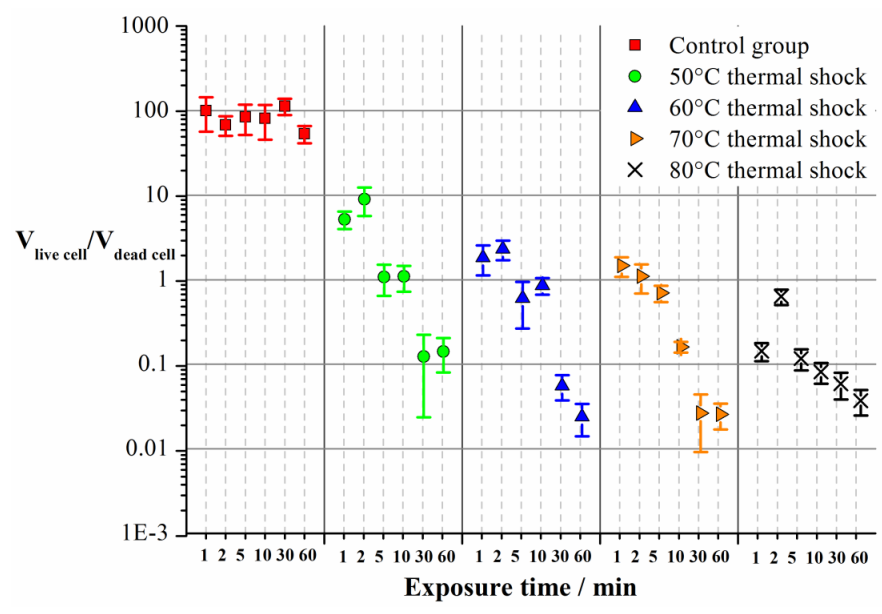

Figure 8. Ratio of the live cell biovolume to the dead cell biovolume of the $120 \mathrm{~h}$ biofilms.

As can be seen in Figure 8, in the control group, the ratios were all close to 100 regardless of the exposure time, suggesting immersing with normal temperature water barely had any bactericidal effects. In the thermal shock groups, the ratio decreased significantly as both the temperature and exposure time increased, suggesting an enhanced bactericidal effect as the temperature and exposure time increased. The minimum ratio was close to 0.01 , suggesting a significant bactericidal effect of the thermal shock.

In summary, it could be concluded from the CLSM figures and the quantitative analysis that as the temperature and exposure time increased, more cells were killed and the amount of the biofilms decreased, leading to an enhanced biofilm inhibition effect.

\subsection{Thermal Resistance of the Biofilms}

Biofilm formation and thermal shock were also performed in the pilot heat exchanging system. Thermal resistance of the biofilms in the plate heat exchanger was calculated and the results are shown in Figure 9.

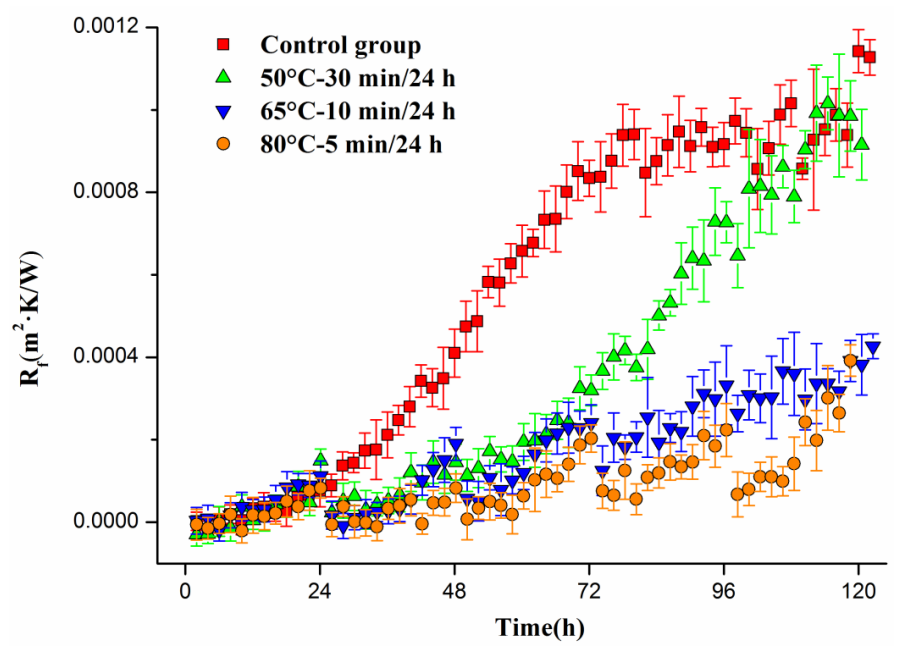

Figure 9. Thermal resistance of the biofilms in the heat exchanger. 
It can be seen in Figure 9 that, for the control group, the thermal resistance increased over time in an S-type curve and reached a stable level of about $1 \times 10^{-3} \mathrm{~m}^{2} \cdot \mathrm{K} / \mathrm{W}$ after $72 \mathrm{~h}$.

For the biofilms thermal shocked at $50{ }^{\circ} \mathrm{C}$ for $30 \mathrm{~min} / 24 \mathrm{~h}$, it can be seen that, at $24 \mathrm{~h}$, the thermal shock caused significant thermal resistance decrease. However, the $48 \mathrm{~h}, 72 \mathrm{~h}$, and $96 \mathrm{~h}$ thermal shocks left no significant impacts on the biofilms and the thermal resistance reached about $1 \times 10^{-3} \mathrm{~m}^{2} \cdot \mathrm{K} / \mathrm{W}$ at $120 \mathrm{~h}$.

For the biofilms thermal shocked at $65^{\circ} \mathrm{C}$ for $10 \mathrm{~min} / 24 \mathrm{~h}$, there were significant thermal resistance decrease due to the thermal shocks at 24,48 and $72 \mathrm{~h}$. The decrease at $96 \mathrm{~h}$ was less obvious, and the thermal resistance reached about $0.4 \times 10^{-3} \mathrm{~m}^{2} \cdot \mathrm{K} / \mathrm{W}$ at $120 \mathrm{~h}$.

For the biofilms thermal shocked at $80^{\circ} \mathrm{C}$ for $5 \mathrm{~min} / 24 \mathrm{~h}$, the thermal resistance decreased close to zero after every thermal shock, suggesting such thermal shock eliminated the majority of the biofilms in the heat exchanger and exhibited a strong biofilm inhibition effect.

\section{Discussion}

Many studies have been carried out to investigate the thermal inactivation of bacteria and biofilm inhibition [33-36,44,45]. Some of these studies, especially those in the fields of food engineering, health care and water supply system, focused on the number of live bacteria cells. In such studies, bacterial cell counts or the dry biomass were measured.

However, in the TSSHPS, the efficiency decrease is mainly caused by the thermal resistance of the biofilms. Previous studies [11,41] have shown that the thermal resistance of the biofilms were linearly correlated with the biofilm thickness and the wet weight. In this study, the thermal resistance is of the main interest and the wet weight of the biofilms, instead of the cell count or the dry biomass, was measured.

In the experiments, the coupons were suspended in air for $5 \mathrm{~min}$ to drain off the surface water-droplets before being weighed. A previous study [13] has reported that 5 min was long enough for all of the extraneous water in the biofilms to be eliminated. The remaining water is stabilized water in the biofilms, and such water acts as a static layer in the biofilms and causes a thermal resistance increase in the heat exchangers. Such water should not be eliminated and the biofilms were weighed with the stabilized water.

Many studies have investigated the data fitting and modelling of the thermal inactivation of planktonic bacteria cells [33-36]. These studies have employed the log linear bacterial survival curves, as shown by Equation (6):

$$
\log N_{\mathrm{t}}=\log N_{0}-\frac{t}{D}
$$

where $N_{\mathrm{t}}$ is the number of live cells after the thermal shock, $N_{0}$ is the number of the live cells without being thermally shocked, $t$ is the exposure time, and $D$ is a constant correlated with temperature.

However, it has been reported that thermal shock efficient to eliminate planktonic bacteria cells barely killed any cells in biofilms [46], suggesting that thermal shock has different bactericidal effects on planktonic cells and on cells in biofilms. Similarly, Equation (6) could not be used for data fitting of the $120 \mathrm{~h}$ biomass (when used, $R^{2}$ in all temperature groups would be less than 0.5 ). Thus, a new formula was needed to correlate the $120 \mathrm{~h}$ biomass $m_{\mathrm{f}}$ to the exposure time $t$.

In this study, a hypothesis was raised that the biomass decrease was correlated with the amount of heat transferred to the biofilms, and the hypothesis could be written as:

$$
m_{\mathrm{f}}=m_{0}-\mathrm{c} \times Q_{t}
$$

where $m_{\mathrm{f}}$ is the $120 \mathrm{~h}$ biomass, $m_{0}$ is the biomass of biofilms without heat treatment, $\mathrm{c}$ is a constant and $Q_{t}$ is the heat transferred to the biofilms within the exposure time. 
The biofilms, which were $20 \mathrm{~mm}$ in length and width and about $100 \mu \mathrm{m}$ in thickness, were considered as infinite plates, and the Biot number of the biofilms was less than 0.05 . The lumped parameter method could be used for heat transfer analysis of the biofilms, and $Q_{t}$ could be written as:

$$
Q_{t}=\left(T-T_{0}\right) \rho c_{\mathrm{p}} V\left[1-\exp \left(-\frac{h A}{\rho c_{\mathrm{p}} V}\right) t\right]
$$

where $T$ is the thermal shock temperature, $T_{0}$ is the initial temperature of the biofilms $\left(25^{\circ} \mathrm{C}\right), \rho, c_{\mathrm{p}}, V$, $h$ and $A$ are the density, special heat, volume, convective heat transfer coefficient, and surface area of the biofilms, and $t$ is the exposure time [47].

For a certain thermal shock temperature and a certain biofilm, Equation (8) could be written as:

$$
Q_{t}=a_{0}[1-\exp (-b t)]
$$

where $a_{0}$ and $b$ are coefficients correlated with temperature.

Equation (9) was substituted into Equation (7), and we got Equation (4) as the fitting equation. The results showed that Equation (4) yielded tight correlations (Figure 5, average $R^{2}=0.9211$ ), indicating it was appropriate to correlate the biomass decrease with the total heat and use Equation (4) as the fitting equation.

In this study, the results of the CLSM pictures indicated that thermal shock killed the bacteria in the biofilms, and this bactericidal effect was enhanced as the temperature and the exposure time increased (Figures 7 and 8). Similar trends have been observed in previous studies $[39,48]$.

A potential explanation for this result has been proposed in previous studies [49-51], i.e., thermal shock disrupts the hydrogen bonding and destroys the structural integrity of viral proteins such as the respiratory enzymes in the bacteria cells, and causes disintegration of the bacterial cell membrane. The results in this study agree with this explanation. In this study, two fluorescent dyes, PI and SYTO ${ }^{\circledR}$ 9, were used for the biofilm staining and CLSM picturing. These dyes are based on membrane integrity, i.e., SYTO ${ }^{\circledR} 9$ enters all cells, fluorescing green in the CLSM, and PI enters only cells with disrupted membranes, quenching SYTO ${ }^{\circledR} 9$ and fluorescing red [39]. It could be seen in the CLSM pictures that the amount of red fluorescence increased significantly as the biofilms were thermal shocked, indicating that the thermal shock killed bacteria cells by damaging the bacterial cell membranes (Figure 7).

It has been reported that the strength of the biofilms would decrease when the cell viability in the biofilms reduced [52-54]. Thus, the potential mechanism for the biofilm inhibition effect in this study is that thermal shock caused disintegration of the bacterial cell membrane and killed the cells in the biofilms. As the cell viability decreased, the biofilms would become more vulnerable and detach from the solid surface, so the biomass and thermal resistance of the biofilms would decrease (Figures 3, 4 and 9).

Many biofilm inhibition strategies could hardly be applied to the plate heat exchangers due to the compactness, closed internal environment of the heat exchangers, and the large flow rate and the environmental protection concerns in the TSSHPS. Thermal shocks, however, could be applied directly in the TSSHPS by stopping the treated sewage supply and pumping in hot water for a short period of time at regular intervals. This study shows that thermal shock with a certain temperature and exposure time could decrease the thermal resistance of the biofilms significantly, indicating that thermal shock is a feasible and efficient biofilm inhibition approach for the TSSHPS.

To determine an appropriate thermal shock protocol for the practical TSSHPS, the influence of the temperature and the exposure time must be understood. In this study, three thermal shock protocols were tested and the amount of heat consumed in these protocols were similar. The results showed that the $80^{\circ} \mathrm{C}-5 \mathrm{~min} / 24 \mathrm{~h}$ thermal shock had the most significant biofilm inhibition effect (Figure 9), indicating that temperature has a more significant influence on the inhibiting effect than the exposure time. This could also be seen from the data fitting results of Equation (5), where $t$ influences only the exponential term, but $T$ influences both the exponential term and the first degree term. These results 
indicate that in practical TSSHPS, thermal shocks at higher temperatures and lower exposure times might be preferred.

\section{Conclusions}

Biofilm formation in the plate heat exchangers is a severe problem in the TSSHPS. In this study, a rotating coupon device and a pilot heat exchanging system were used to investigate the biofilm inhibition effect of the thermal shock and the influence of temperature and exposure time. The results shown by the biomass development and CLSM pictures indicate that thermal shock kills the bacteria cells in the biofilms by damaging the bacterial cell membranes, makes the biofilms more vulnerable and decreases the biomass and the biovolume significantly. The results of the heat exchanging experiments and of the data fitting show that thermal shock is effective in decreasing the thermal resistance of biofilms and temperature has a more significant influence than exposure time. In summary, thermal shock could be a viable approach towards the biofilm control in practical TSSHPS and thermal shock at higher temperatures and lower exposure times should be preferred.

Acknowledgments: This work was supported by The National Natural Science Foundation of China (grant No. 51476090 and grant No. 50976060) and The Science Fund for Creative Research Group (grant No. 51621062).

Author Contributions: Lin Shi provided the guidance and supervision. Siyuan Chang implemented the main research and wrote the paper. Jinchun Chen provided guidance for the microbiological experiments. All authors have read and approved the submission of the manuscript.

Conflicts of Interest: The authors declare no conflict of interest.

\section{References}

1. Chan, Y.J.; Chong, M.F.; Law, C.L.; Hassell, D.G. A review on anaerobic-aerobic treatment of industrial and municipal wastewater. Chem. Eng. J. 2009, 155, 1-18. [CrossRef]

2. Loos, R.; Carvalho, R.; Antonio, D.C.; Comero, S.; Locoro, G.; Tavazzi, S.; Paracchini, B.; Ghiani, M.; Lettieri, T.; Blaha, L.; et al. EU-wide monitoring survey on emerging polar organic contaminants in wastewater treatment plant effluents. Water Res. 2013, 47, 6475-6487. [CrossRef] [PubMed]

3. Guest, J.S.; Skerlos, S.J.; Barnard, J.L.; Beck, M.B.; Daigger, G.T.; Hilger, H.; Jackson, S.J.; Karvazy, K.; Kelly, L.; Macpherson, L.; et al. A new planning and design paradigm to achieve sustainable resource recovery from wastewater. Environ. Sci. Technol. 2009, 43, 6126-6130. [CrossRef] [PubMed]

4. Meggers, F; Leibundgut, $H$. The potential of wastewater heat and energy: Decentralized high-temperature recovery with a heat pump. Energy Build. 2011, 43, 879-886. [CrossRef]

5. Cipolla, S.S.; Maglionico, M. Heat recovery from urban wastewater: Analysis of the variability of flow rate and temperature. Energy Build. 2014, 69, 122-130. [CrossRef]

6. Yang, Q.P.; Chang, S.Y.; Shi, L. Study on interactions between suspended matter and biofouling formed by treated sewage. Environ. Technol. 2015, 36, 2778-2785. [CrossRef] [PubMed]

7. Funamizu, N.; Iida, M.; Sakakura, Y.; Takakuwa, T. Reuse of heat energy in wastewater: Implementation examples in Japan. Water Sci. Technol. 2001, 43, 277-285. [PubMed]

8. Tian, L.; Chen, X.D.; Yang, Q.P.; Chen, J.C.; Shi, L.; Li, Q. Effect of calcium ions on the evolution of biofouling by Bacillus subtilis in plate heat exchangers simulating the heat pump system used with treated sewage in the 2008 Olympic Village. Colloids Surf. B 2012, 94, 309-316. [CrossRef] [PubMed]

9. Ahmed, W.; Yusuf, R.; Hasan, I.; Goonetilleke, A.; Gardner, T. Quantitative PCR assay of sewage-associated Bacteroides markers to assess sewage pollution in an urban lake in Dhaka, Bangladesh. Can. J. Microbiol. 2010, 56, 838-845. [CrossRef] [PubMed]

10. Khan, S.S.; Kumar, E.B.; Mukherjee, A.; Chandrasekaran, N. Bacterial tolerance to silver nanoparticles (SNPs): Aeromonas punctate isolated from sewage environment. J. Basic Microbiol. 2010, 51, 183-190. [CrossRef] [PubMed]

11. Yang, Q.P.; Wilson, D.I.; Chang, S.Y.; Shi, L. A new approach for mitigating biofouling by promoting online cleaning using a sacrificial paraffin coating. Heat Transf. Eng. 2015, 36, 695-705. [CrossRef] 
12. Murthy, P.S.; Venkatesan, R.; Nair, K.V.K.; Ravindran, M. Biofilm control for plate heat exchangers using seawater from the open ocean for the OTEC power plant. Int. Biodeterior. Biodegrad. 2004, 53, $133-140$. [CrossRef]

13. Tian, L.; Chen, X.D.; Yang, Q.P.; Chen, J.C.; Li, Q.; Shi, L. Effect of silica dioxide particles on the evolution of biofouling by Bacillus subtilis in plate heat exchangers relevant to a heat pump system used with treated sewage. Chem. Eng. J. 2012, 188, 47-56. [CrossRef]

14. Stoodley, P.; Sauer, K.; Davies, D.G.; Costerton, J.W. Biofilms as complex differentiated communities. Annu. Rev. Microbiol. 2002, 56, 187-209. [CrossRef] [PubMed]

15. Bester, E.; Edwards, E.A.; Wolfaardt, G.M. Planktonic cell yield is linked to biofilm development. Can. J. Microbiol. 2009, 55, 1195-1206. [CrossRef] [PubMed]

16. Steinhagen, R.; Müller-steinhagen, H.; Maani, K. Problems and costs due to heat exchanger fouling in New Zealand industries. Heat Transf. Eng. 1993, 14, 19-30. [CrossRef]

17. Dahlström, M.; Jonsson, H.; Jonsson, P.R.; Elwing, H. Surface wettability as a determinant in the settlement of the barnacle Balanus improvisus (DARWIN). J. Exp. Mar. Biol. Ecol. 2004, 305, 223-232. [CrossRef]

18. Vinh, D.C.; Embil, J.M. Device-related infections: A review. J. Long Term Eff. Med. Implants 2005, 15, 467-488. [CrossRef] [PubMed]

19. Cavallaro, A.; Mierczynska, A.; Barton, M.; Majewski, P.; Vasilev, K. Influence of immobilized quaternary ammonium group surface density on antimicrobial efficacy and cytotoxicity. Biofouling 2016, 32, 13-24. [CrossRef] [PubMed]

20. Stoodley, P.; Wilson, S.; Hall-Stoodley, L.; Boyle, J.D.; Lappin-Scott, H.M.; Costerton, J.W. Growth and detachment of cell clusters from mature mixed-species biofilms. Appl. Environ. Microbiol. 2001, 67, 5608-5613. [CrossRef] [PubMed]

21. Bandara, H.M.H.N.; Nguyen, D.; Mogarala, S.; Osiñski, M.; Smyth, H.D.C. Magnetic fields suppress Pseudomonas aeruginosa biofilms and enhance ciprofloxacin activity. Biofouling 2015, 31, 443-457. [CrossRef] [PubMed]

22. Galván, E.M.; Mateyca, C.; Ielpi, L. Role of interspecies interactions in dual-species biofilms developed in vitro by uropathogens isolated from polymicrobial urinary catheter-associated bacteriuria. Biofouling 2016, 32, 1067-1077. [CrossRef] [PubMed]

23. Sandt, C.; Barbeau, J.; Gagnon, M.A.; Lafleur, M. Role of the ammonium group in the diffusion of quaternary ammonium compounds in Streptococcus mutans biofilms. J. Antimicrob. Chemother. 2007, 60, 1281-1287. [CrossRef] [PubMed]

24. Scardino, A.J.; de Nys, R. Mini review: Biomimetic models and bioinspired surfaces for fouling control. Biofouling 2011, 27, 73-86. [CrossRef] [PubMed]

25. Chung, K.K.; Schumacher, J.F.; Sampson, E.M.; Burne, R.A.; Brennan, A.B. Impact of engineered surface microtopography on biofilm formation of Staphylococcus aureus. Biointerphases 2007, 2, 89-94. [CrossRef] [PubMed]

26. Traba, C.; Liang, J.F. Susceptibility of Staphylococcus aureus biofilms to reactive discharge gases. Biofouling 2011, 27, 763-772. [CrossRef] [PubMed]

27. Brassard, J.D.; Sarkar, D.K.; Perron, J. Fluorine based superhydrophobic coatings. Appl. Sci. 2012, 2, $453-464$. [CrossRef]

28. Rene, H.D.; Jose, M.S.; Isela, S.N.; Claudio, C.R. Effects of ambroxol on Candida albicans growth and biofilm formation. Mycoses 2013, 57, 228-232. [CrossRef] [PubMed]

29. Peng, Z.X.; Wang, L.; Du, L.; Guo, S.R.; Wang, X.Q.; Tang, T.T. Adjustment of the antibacterial activity and biocompatibility of hydroxypropyltrimethyl ammonium chloride chitosan by varying the degree of substitution of quaternary ammonium. Carbohydr. Polym. 2010, 81, 275-283. [CrossRef]

30. Alves, D.; Pereira, M.O. Mini-review: Antimicrobial peptides and enzymes as promising candidates to functionalize biomaterial surfaces. Biofouling 2014, 30, 483-499. [CrossRef] [PubMed]

31. Aguiar, H.F.; Gut, J.A.W. Continuous HTST pasteurization of liquid foods with plate heat exchangers: Mathematical modeling and experimental validation using a time-temperature integrator. J. Food Eng. 2014, 123, 78-86. [CrossRef]

32. Vickery, K.; Pajkos, A.; Cossart, Y. Evaluation of the effectiveness of decontamination of dental syringes. Br. Dent. J. 2000, 189, 620-624. [CrossRef] [PubMed] 
33. Cunha, L.M.; Oliveira, F.A.R.; Oliveira, J.C. Optimal experimental design for estimating the kinetic parameters of processes described by the Weibull probability distribution function. J. Food Eng. 1998, 37, 175-191. [CrossRef]

34. Campanella, O.H.; Peleg, M. Theoretical comparison of a new and the traditional method to calculate Clostridium botulinum survival during thermal inactivation. J. Sci. Food Agric. 2001, 81, 1069-1076. [CrossRef]

35. Sakkaf, A.A.; Jones, G. Thermal inactivation of Campylobacter jejuni in broth. J. Food Prot. 2012, 75, 1029-1035. [CrossRef] [PubMed]

36. Monu, E.A.; Valladares, M.; D'Souza, D.H.; Davidson, P.M. Determination of the thermal inactivation kinetics of Listeria monocytogenes, Salmonella enterica, and Escherichia coli O157:H7 and non-O157 in buffer and a spinach homogenate. J. Food Prot. 2015, 78, 1467-1471. [CrossRef] [PubMed]

37. Donlan, R.M.; Costerton, J.W. Biofilms: Survival mechanisms of clinically relevant microorganisms. Clin. Microbiol. Rev. 2002, 15, 167-193. [CrossRef] [PubMed]

38. Chmielewski, R.A.; Frank, J.F. A predictive model for heat inactivation of Listeria monocytogenes biofilm on stainless steel. J. Food Prot. 2004, 67, 2712-2718. [CrossRef] [PubMed]

39. O'Toole, A.; Ricker, E.B.; Nuxoll, E. Thermal mitigation of Pseudomonas aeruginosa biofilms. Biofouling 2015, 31, 665-675. [CrossRef] [PubMed]

40. Villa-Rojas, R.; Zhu, M.J.; Paul, N.C.; Gray, P.; Xu, J.; Shah, D.H.; Tang, J.M. Biofilm forming Salmonella strains exhibit enhanced thermal resistance in wheat flour. Food Control 2017, 73, 689-695. [CrossRef]

41. Yang, Q.P.; Wilson, D.I.; Chen, X.D.; Shi, L. Experimental investigation of interactions between the temperature field and biofouling in a synthetic treated sewage stream. Biofouling 2013, 29, 513-523. [CrossRef] [PubMed]

42. Imaris for Biofilm Research. Available online: http://www.bitplane.com/biofilms.aspx (accessed on 29 March 2017).

43. Yang, S.M.; Tao, W.Q. Heat Transfer, 4th ed.; Higher Education Press: Beijing, China, 2006; pp. $435-446$.

44. Singh, R.; Kim, J.; Jiang, X. Heat inactivation of Salmonella spp. in fresh poultry compost by simulating early phase of composting process. J. Appl. Microbiol. 2012, 112, 927-935. [CrossRef] [PubMed]

45. Pohl, S.; Madzgalla, M.; Manz, W.; Bart, H.J. Biofouling on polymeric heat exchanger surfaces with E. coli and native biofilms. Biofouling 2015, 31, 699-707. [CrossRef] [PubMed]

46. Rodrigues, D.; Bañobre-López, M.; Espiña, B.; Rivas, J.; Azeredo, J. Effect of magnetic hyperthermia on the structure of biofilm and cellular viability of a food spoilage bacterium. Biofouling 2013, 29, 1225-1232. [CrossRef] [PubMed]

47. Yang, S.M.; Tao, W.Q. Heat Transfer, 4th ed.; Higher Education Press: Beijing, China, 2006; pp. 112-123.

48. Li, Y.; Yang, H.; Swem, B.L. Effect of high-temperature inside-outside spray on survival of Campylobacter jejuni attached to prechill chicken carcasses. Poult. Sci. 2002, 81, 1371-1377. [CrossRef] [PubMed]

49. Park, H.; Park, H.J.; Kim, J.A.; Lee, S.H.; Kim, J.H.; Yoon, J.; Park, T.H. Inactivation of Pseudomonas aeruginosa PA01 biofilms by hyperthermia using superparamagnetic nanoparticles. J. Microbiol. Methods 2011, 84, 41-45. [CrossRef] [PubMed]

50. Meyer, A.S.; Baker, T.A. Proteolysis in the Escherichia coli heat shock response: A player at many levels. Curr. Opin. Microbiol. 2011, 14, 194-199. [CrossRef] [PubMed]

51. Kramer, B.; Thielmann, J. Monitoring the live to dead transition of bacteria during thermal stress by a multi-method approach. J. Microbiol. Methods 2016, 123, 24-30. [CrossRef] [PubMed]

52. Fabrega, J.; Renshaw, J.C.; Lead, J.R. Interactions of silver nanoparticles with Pseudomonas putida biofilms. Environ. Sci. Technol. 2009, 43, 9004-9009. [CrossRef] [PubMed]

53. Christophis, C.; Taubert, I.; Meseck, G.R.; Schubert, M.; Grunze, M.; Ho, A.D.; Rosenhahn, A. Shear stress regulates adhesion and rolling of CD44+ leukemic and hematopoietic progenitor cells on hyaluronan. Biophys. J. 2011, 101, 585-593. [CrossRef] [PubMed]

54. Chavez-Dozal, A.A.; Jahng, M.; Rane, H.S.; Asare, K.; Kulkarny, V.V.; Bernardo, S.M.; Lee, S.A. In vitro analysis of flufenamic acid activity against Candida albicans biofilms. Int. J. Antimicrob. Agents 2013, 43, 86-91. [CrossRef] [PubMed]

(C) 2017 by the authors. Licensee MDPI, Basel, Switzerland. This article is an open access article distributed under the terms and conditions of the Creative Commons Attribution (CC BY) license (http:/ / creativecommons.org/licenses/by/4.0/). 